\title{
The surface Temperature of the North Atlantic during 1911.
}

By

Commander M. W. Campbell Hepworth, C. B., R. D., R. N. R.

During the greater part of the past year (1911) the surface temperature ot the North Atlantic was mainly above the normal; and from the end of June to the and of September largely in excess of the average.

It has occurred to me that a brief statement regarding the most striking departures from average conditions in the several months may be of interest to those who are interested in Oceanography.

The information I have gained in this connexion is based upon observations contributed by regular observers to the British Meteorological Office; and the results may therefore be regarded as reliable. The number of the observations utilized in the tabulation of these results, which are charted weekly, is about 50 for each week.

In the first seven day of January the surface temperature of the North Atlantic was found to have been slightly above the normal, and during the remainder of the month decidedly above. It differed little from the average, over the greater part of the Ocean, in February, but was below on the eastern side in the first week; between the $38^{\text {th }}$ and $42^{\text {nd }}$ parallels, and the $20^{\text {th }}$ and $50^{\text {th }}$ meridians in the second week; and eastward of the $28^{\text {th }}$ meridian in the fourth week.

In the earlier days of March an area of relatively cold water was located between $44^{\circ} \mathrm{N}$. and $50^{\circ} \mathrm{N}$.; $43^{\circ} \mathrm{W}$. and $44^{\circ} \mathrm{W}$. Subsequently the temperature of the surface immediately to the west of the British Islands fell considerably below the average; this diminution of temperature being due, presumably, to an increased activity, and encroachment of the Greenland Current. In other parts of the North Atlantic at this period the surface temperature remained above the normal. 
The zone of relatively cold water maintained its position to the west of our Islands until the second week of April; while to the westward of it the surface was found to be relatively warm, and in other parts of the Ocean, about normal. From about the $9^{\text {th }}$ April to the $20^{\text {th }}$ May the sea surface temperature was, for the most part, about the average; except in the south-western portion of the Ocean where, owing obviously to an increase in volume of the Gulf Stream, and to its extension north-eastward, the temperature from between the $44^{\text {th }}$ meridian and the west coast of Ireland south-westward rose above the normal.

Towards the close of May observations of surface water showed considerable positive departures from the normal in the south-western part of the Ocean, its temperature continuing to rise; so that at the end of the month the $70^{\circ}$ isotherm when charted was shown more than 450 miles east-north-eastward of its average limit for the time of year.

A slight diminution of temperature, which occurred towards the end of May in the north-western arm of the Ocean, and subsequently spread south-eastward, was traced to the agency of the Labrador Current. It lasted to about the middle of June, after which the surface temperature differed little from the average until the beginning of July. From the first week in July to the close of September sea temperature was found to have been considerably in excess of the average, in all parts of the North Atlantic for which reliable data are available.

Throughout October, and the three succeeding weeks of November, the observations collected showed little or no difference from the normal, and where departures occured the lower temperatures were located largely in the north-west arm of the Ocean, but always north of the parallels of $40^{\circ}$ to $45^{\circ}$; while the higher temperatures were confined to latitudes south of those parallels.

During the remaining days of November surface temperature, which had declined in the third week of that month, remained below the average generally; but it recovered in December.

Observations contributed to the Meteorological Office by the Captains of Whaling Ships, cruising in Davis Strait and Baffin Bay, afford evidence of unusually boisterous weather and abnormal snowfall in the east Greenland quadrant of the Aretic, during the summer of last year. Gales were frequent, and the wind on many occasions attained to the force of a whole gale, and on one occasion to that of a hurricane. The frequency of snow may be judged by the fact that approximately 
20 per cent of all four hourly observations of weather recorded on board one of the Ships from which records were received, the "Diana", included entries relating to the precipitation of snow.

This open weather may be accounted for by the prevailing distribution of atmospheric pressure over the northern portion of the North Atlantic, and Western Europe, during the greater part of the nine month's period, January to September inclusive; which was such as to keep most of the areas of low pressure moving eastward, in high latitudes. This pressure distribution was most marked in the months of January to March, in May, and again in the months of July to September, when areas of high barometer were frequently present over the North Atlantic south of the $55^{\text {th }}$ parallel; over the western half of the Continent; and, occasionally, but chiefly in the earlier months of the year, over Russia. Under these conditions the paths of a large percentage of the depressions arriving from the west were deflected to the north-eastward, and in numerous instances their centres moved from the north-west arm of the Atlantic across, or to the north of Iceland; ultimately disappearing over the Arctic, beyond the North Cape.

The increasing activity of the Labrador Current during the first four months of the year, was evinced by the rapid increase in the quantity of ice brought by this current into the north-western Atlantic during that period.

The relatively high surface temperature of the Ocean during the past summer cannot, in my opinion, be attributed to any diminution in the volume of cold water from Polar Seas, but must have been caused by a more than usually large influx of warm water from Equatorial regions, transmitted through the agency of the Gulf Stream.

From a comparison of the changes in the temperature of the waters of the North Atlantic and in the strength of the Trade Winds, during the years 1902-1907, undertaken by the writer in 1908, the results of which were subsequently published, it was concluded that a relation could be traced between departures from the average in the velocities of the north-east and south-east Trade Winds in any one year, and deviations from the normal in the distribution of surface temperature in the North Atlantic in the succeeding year. There appeared indeed to be considerable evidence to prove that variations in the average strength of the Trades during a series of months, and at times during even so short a period as one month, were roughly reflected in the distribution of surface temperature in the North Atlantic in the corresponding series of months or month, as the case may be, of the following year. 
The increase in the volume of the Gulf Stream during the Spring and Summer of 1911 may, therefore, have been due to increased velocities of the Trade Winds in the year 1910; and the weather during the Winter of last year may have been, like the Spring and Summer, stormy, and the season therefore open. In this way the increased activity of the Greenland and Labrador Currents in the Spring of last year may be accounted for.

Nachtrag, 29:th April 1912.

There are now large quantities of ice in the neighbourhood of the Banks of Newfoundland. The first iceberg reported this year was seen on the $7^{\text {th }}$ January in about $46^{\circ} \mathrm{N}$., $53^{\circ} \mathrm{W}$., but ice has been present in the North-Western Atlantic since January of last year.

The Steamship Cassandra passed field-ice on the $7^{\text {th }}$ of this month in $43^{\circ} 20^{\prime} \mathrm{N}$., $49^{\circ} 15^{\prime} \mathrm{W}$, which was said to be at least 50 miles in extent. On the following day, in $43^{\circ} 28^{\prime} \mathrm{N} ., 49^{\circ}, 36^{\prime}$ W. large fields of ice, studdied with bergs, were observed from the deck of the S. S. Empress of Britain, as far as the eye could reach; and on the $11^{\text {th }}$, in $41^{\circ} 58^{\prime} \mathrm{N}$., $50^{\circ} 20^{\prime} \mathrm{W}$., the Carmania passed much field-ice, and numerous bergs. The S. S. Niagara collided with ice, and damaged her bottom.

On the $14^{\text {th }}$ the Titanic came into collision with an iceberg, in $41^{\circ} 16^{\prime} \mathrm{N} ., 50^{\circ} 14^{\prime} \mathrm{W}$, and foundered.

Several other steamers sustained damage through collision with ice, and reports of ice have been, and continue to be numerous. Ice has drifted south earlier than usual this year, and it appears probable that much of it was broken up during the stormy weathers in the Aretic last spring and summer, and drifted south in Davis' Strait and out of Hudson Strait, reaching the coast of Labrador, and some of it even farther south, before the winter set in. 